\title{
Spontaneous Gene Flow between Cultivated and Naturalized Vicia villosa Roth Populations Increases the Physical Dormancy Seed in a Semiarid Agroecosystem
}

\author{
Juan Pablo Renzi ${ }^{1,2, *(\mathbb{D}, \text { Omar Reinoso }}{ }^{1}$, Matías Quintana ${ }^{1}$ and Petr Smýkal ${ }^{3}$ (D) \\ 1 Instituto Nacional de Tecnología Agropecuaria, Hilario Ascasubi 8142, Argentina; \\ reinoso.omar@inta.gob.ar (O.R.); quintana.m@inta.gob.ar (M.Q.) \\ 2 Departamento de Agronomía, Universidad Nacional del Sur, San Andrés 800, Bahía Blanca 8000, Argentina \\ 3 Department of Botany, Palacký University in Olomouc, Šlechtitelů 27, 78371 Olomouc, Czech Republic; \\ petr.smykal@upol.cz \\ * Correspondence: renzipugni.juan@inta.gob.ar
}

check for

updates

Citation: Renzi, J.P.; Reinoso, O.;

Quintana, M.; Smýkal, P.

Spontaneous Gene Flow between

Cultivated and Naturalized Vicia

villosa Roth Populations Increases the

Physical Dormancy Seed in a

Semiarid Agroecosystem. Agronomy

2021, 11, 955. https://doi.org/

10.3390/agronomy11050955

Academic Editor: Jose Maria Barrero

Received: 16 April 2021

Accepted: 11 May 2021

Published: 12 May 2021

Publisher's Note: MDPI stays neutral with regard to jurisdictional claims in published maps and institutional affiliations.

Copyright: (c) 2021 by the authors. Licensee MDPI, Basel, Switzerland. This article is an open access article distributed under the terms and conditions of the Creative Commons Attribution (CC BY) license (https:/ / creativecommons.org/licenses/by/ $4.0 /)$.

\begin{abstract}
Hairy vetch (Vicia villosa Roth) is the second most cultivated vetch worldwide being used as a forage and cover crop. As it is not domesticated, it displays several wild traits including seed dormancy. The physical seed dormancy (PY) variation could be useful depending on the specific context. High PY is desirable for ley farming systems, while low PY is needed to prevent weediness in subsequent crop rotations. Gene flow between cultivated and naturalized populations has important ecological and agronomic consequences. Experiments were conducted to determine the change in the level of PY in spontaneous crosses between European cultivated accessions (EU) characterized by low PY and naturalized Argentinian population (AR) with high PY. Generations $G_{0}$ (initial generation) to $\mathrm{G}_{3}$ were assessed for their PY in seeds and total dry matter (DM) per plot, at plant maturity. As the result of spontaneous crosses with the AR population, an increase from $G_{0}$ to $G_{3}$ in $P Y$ and DM in EU accessions was observed, while AR maintained its high PY and DM values. In one mating cycle, selecting for PY lower than 14\% and high DM can satisfy breeding objectives for cover crops. Isolation during breeding and seed production is necessary to avoid gene flow. This knowledge extends to other legume species with gene flow between wild and cultivated populations.
\end{abstract}

Keywords: breeding; cover crops; hairy vetch; pasture legume; seed dormancy

\section{Introduction}

Vicia villosa Roth, commonly known as hairy vetch (HV), is native to Europe and West Asia and was introduced as a crop or weed worldwide to temperate climate regions [1,2]. Generally, it is grown for forage, consumed under direct or indirect grazing or used as green manure. The use of $\mathrm{HV}$ as a cover crop in conservation agriculture is increasing [3,4].

HV shows the capacity to form spontaneous populations in ruderal habitats of cultivated areas $[4,5]$. Argentinian HV was used as forage and escaped from cultivation a century ago and formed naturalized populations [6]. The ability of HV seeds to have physical dormancy (PY) results in soil seed bank formation and pod dehiscence, which are two important factors that influence natural population dynamics and persistence $[7,8]$. In $\mathrm{HV}$, the acquisition of PY is initiated when the moisture content of the seeds is $\leq 14 \%[9,10]$. At seed dispersal, the proportion of seeds with PY was $74 \%$ on average in the naturalized AR population [11,12]. Despite the effect of the environment, seed dormancy is largely genetically determined and is variable among genotypes, and this is used in breeding selection [8,13-15]. The most important traits for which HV has been selected include biomass production and a low level of seed dormancy [13]. Low PY is a desirable trait for stand establishment [8], while incomplete germination related to PY can result in soil seed bank formation and emergence in subsequent crop rotations as a problematic weed $[8,16,17]$. 
On the contrary, in the agroecosystems of semiarid regions, HV's natural reseeding capacity with high PY is a desirable trait. The adoption of HV is associated with its high self-regeneration potential, which is known in ley farming in Australian systems and helps to reduce production costs, minimalizing the seed and sowing operations [17-20].

In Argentina, as in other regions of the world, several HV naturalized populations have been established in ruderal habitats surrounding agricultural areas [4,5]. The semiarid region of Argentina shows favorable conditions for cultivated HV biomass and seed production, as well as suitable habitats for naturalized HV populations [6]. Furthermore, $\mathrm{HV}$ is mainly a cross-pollinated species for which bees play an important role [21]; thus, dry and warm weather is favorable for the activity of pollinators [22,23]. It is known that naturalized populations of HV have high degrees of PY [6]. The sympatric occurrence of an $\mathrm{HV}$ crop and naturalized populations might increase the frequency of pollinator-mediated gene flow. Consequently, changes in gene frequency can modify traits of interest including the PY level [6,24]. Gene flow-mediated changes in PY may be relevant for breeding and seed production programs, as well as for the study of HV demography from a weed management perspective or ley farming systems in an agricultural environment.

The objective of this study was the evaluation of the changes in PY level as a result of spontaneous crosses between naturalized HV genotype and European (EU) cultivars characterized by the low PY. The change towards low PY could reduce the adaptation of naturalized HV populations or cultivars for ley farming purposes. On the other hand, higher levels of PY could increase the frequency of HV as a problematic weed.

\section{Materials and Methods}

\subsection{Seed Collection Sources}

Hairy vetch at the Experimental Agricultural Station (EEA) Hilario Ascasubi was selected as the representative of the naturalized populations of Argentina (AR) [12]. The Ascasubi population was located in the southern area of the semiarid region of Argentina, in a sandy loam soil $(\mathrm{pH}=7.5$, soil organic matter $=1.2 \%$, available $\mathrm{P}$ Bray and Kurtz $\left.=24 \mathrm{mg} \mathrm{kg}^{-1}\right)$ along an internal road margin of EEA H. Ascasubi $\left(62^{\circ} 37^{\prime} \mathrm{W}\right.$, $\left.39^{\circ} 23^{\prime} \mathrm{S}\right)$. The predominant climate in this habitat is semiarid temperate with $489 \mathrm{~mm}$ if mean annual precipitation and a mean annual temperature of $14.8{ }^{\circ} \mathrm{C}(1966-2016$; http:/ /inta.gob.ar/documentos/informes-meteorologicos, accessed on 16 April 2021). This population was spontaneously crossed with other HV accessions, including four cultivated accessions from Europe-Asia (EU) that were characterized by low physical seed dormancy (PY) in relation to the naturalized genotypes (Table 1) [6]. Passport data of each EU accession were provided by the Research Institute of Crop Production (CRI), Czech Republic (Table 1; for more information, see https://grinczech.vurv.cz/gringlobal/search.aspx, accessed on 20 March 2021) [12].

Table 1. Country, name of hairy vetch accessions included in the study and average level of seeds' physical dormancy (PY).

\begin{tabular}{cccc}
\hline Country of Origin & Accession/Locality & Number $^{*}$ & PY Level \\
\hline Poland & Sielecka & $05 \mathrm{~L} 1700015$ & $<12 \%$ \\
Turkey & 61781 & $05 \mathrm{~L} 1700046$ & $<12 \%$ \\
Germany & Oregon & $05 \mathrm{~L} 1700066$ & $<30 \%$ \\
Russia & Stavchanka & $05 \mathrm{~L} 1700061$ & $<23 \%$ \\
Argentina & Ascasubi & - & $>72 \%$ \\
\hline
\end{tabular}

* EVIGEZ: Plant Genetic Resources Documentation of the Czech Republic. ${ }^{* *}$ From [6].

\subsection{Seed Production for Comparative PY Experiments}

Seeds from each accession (Table 1) were cultivated at the EEA of Hilario Ascasubi during the 2017-2020 growing seasons. The soil was an entic haplustoll, sandy loam, slightly alkaline $(\mathrm{pH} \approx 7.5)$, high in phosphorus $(\mathrm{P})$ content $(\approx 22 \mathrm{ppm} P$ Bray and Kurtz) 
and low in organic matter content $(\approx 1.6 \%)$ at $20 \mathrm{~cm}$. Weather data from each year were registered with a meteorological station located nearby (less than $700 \mathrm{~m}$ ).

The accessions were arranged in row plots in a randomized complete block design with three replications. Each experimental unit was a row of $2 \mathrm{~m}$ sown with 20 seeds during May. Seeds were inoculated with commercial inoculum (Rhizobium leguminosarum bv viciae) immediately before sowing. Original seeds $\left(\mathrm{G}_{0}\right)$ were used in 2017-2020, and seeds from spontaneous crosses of $G_{1}$ were used in 2018-2020, $G_{2}$ in 2019 and 2020 and $\mathrm{G}_{3}$ in 2020. Regarding the crossing plots design, the relations of $\mathrm{G}_{0}-\mathrm{G}_{1}-\mathrm{G}_{2}-\mathrm{G}_{3}$ were as follows: $100 \% \mathrm{G}_{0}$ in $2017,50 \% \mathrm{G}_{0}-50 \% \mathrm{G}_{1}$ in $2018,33 \% \mathrm{G}_{0}-33 \% \mathrm{G}_{1}-33 \% \mathrm{G}_{2}$ in 2019 , and $25 \% \mathrm{G}_{0}-25 \% \mathrm{G}_{1}-25 \% \mathrm{G}_{2}-25 \% \mathrm{G}_{3}$ in 2020 . The AR naturalized HV population occupied one-fifth of the experimental trials.

Honey bees (Apis mellifera L.) were used as pollinators. The nearest apiary containing 20 colonies was $<400 \mathrm{~m}$ from the study site. Colonies were moved into the experimental site in early November at full-bloom stage. In addition, an original $\left(\mathrm{G}_{0}\right)$ Stavchanka cultivar was multiplied in exclusion cages $(4 \times 6 \mathrm{~m})$ with honey bees (one nucleus) as a control genotype during the three years (2018-2020) in order to maintain genetic purity and avoid contamination.

Seeds for PY testing were immediately harvested from mature pods (mid-December) and threshed by hand. The seeds collected as $\mathrm{G}_{0}$ were used in the next growing season as $G_{1}$, with $G_{1}$ as $G_{2}$ and $G_{2}$ as $G_{3}$ in subsequent seasons. Above-ground total dry matter (DM) was measured at harvest by cutting plant shoots at ground level in a $2 \mathrm{~m}$ row in each plot in 2018 and 2020. The seed moisture content at harvest was $9.2 \pm 1.1 \%$.

\subsection{PY-Dormancy Testing}

Immediately after harvest from the common garden, seeds were cleaned and their seed weight was estimated in a sample of 100 seeds $(n=3)$. PY seeds (i.e., "hard" or impermeable) were determined by an imbibition test performed at $20 \pm 2{ }^{\circ} \mathrm{C}$ for 3 days [12]. Intact seeds were placed on moist filter paper in Petri dishes in replicas and watered daily with tap water. Imbibed seeds showed a visible change in their size/volume ratio and were easily distinguished [11]. Seed viability was assessed for remaining non-germinated seeds by slicing them longitudinally and immersing them in a $0.5 \%(\mathrm{wt} / \mathrm{vol})$ tetrazolium chloride (2,3,5-triphenyltetrazolium chloride) solution for $24 \mathrm{~h}$ at $30{ }^{\circ} \mathrm{C}$ in the dark [25]. Seeds with pink or red stained embryos were considered viable. The total number of viable seeds consisted of germinated and stained seeds.

\subsection{Seed Burial Experiments}

During January 2019, at the onset of the summer season after natural seed dispersal, batches of 100 seeds $(n=3)$ of five genotypes (Table 1$)$ of original $\left(G_{0}\right)$ and spontaneous crosses $\left(G_{1}\right.$ and $\left.G_{2}\right)$ were placed inside permeable nylon mesh bags $(10 \times 10 \mathrm{~cm})$ and buried in the field at a depth of $3 \mathrm{~cm}$ in a bare-soil site (without vegetation or litter) in order to conduct testing under natural soil conditions (diffusion of air and water, micro-organisms, etc.). A completely randomized factorial design was used. Seeds were exhumed after 0 , 120, 190, 280 and 380 days of burial (DAB). Hard, non-imbibed seeds were counted and the proportion of PY seeds was assessed. The remaining hard seeds (with PY) in each exhumation time were returned to the mesh pouches in the field, and the process was repeated to generate cumulative hard seed breakdown curves [26]. The fraction of PY seeds was plotted as a function of burial time.

\subsection{Statistical Analysis}

A linear mixed model (LMM) was performed to test if the accessions differed in the proportion of PY after harvest, breaking (only 2019), seed weight and biomass DM (2018 and 2020), using the accessions and generations $\left(\mathrm{G}_{0}-\mathrm{G}_{3}\right)$ as fixed factors and the year as a random factor. The LMM was performed with $\mathrm{R}$ version 3.6.3 (R Development Core Team 2019) using the Infostat software [27] interface to R. Accessions and generations means 
were compared by Fisher's Least Significant Difference test $(p<0.05)$. For analyses, the PY data were arcsin-square root-transformed; the untransformed data are presented here for clarity. The relationship between PY level, generations and DM was plotted. A regression analysis was performed using GraphPad Prism Software version 8.0 (GraphPad, San Diego, CA, USA).

\section{Results}

Registered rainfall in EEA Hilario Ascasubi during the 2017, 2018 and $2020 \mathrm{HV}$ growing season (from April to December) was within the range of conditions for the semiarid region of Argentina ( $335 \mathrm{~mm})$, and the level was 27\% lower $(241 \mathrm{~mm})$ in 2019 compared to historical long-term means $(331 \mathrm{~mm})$. Mean daily air temperature values were slightly higher in $2018-2020\left(13.4^{\circ} \mathrm{C}\right)$ compared to $2017\left(12.9^{\circ} \mathrm{C}\right)$ (Figure S1). All HV accessions performed well, and it was possible to collect seeds for PY testing.

At harvest, the seed moisture content of all HV genotypes was less than $10 \%$. Seed viability was over $95 \%$ in all cases. No significant interaction between genotypes and generations was found in the seed weight $(p>0.05)$. Stavchanka and Sielecka cultivars had a slightly smaller seed weight ( $31.8 \pm 4.4 \mathrm{mg}$ ) in comparison to 617 81, Oregon and AR (35.1 $\pm 3.5 \mathrm{mg})$.

Regarding seeds of the first generation $\left(\mathrm{G}_{0}\right)$, AR showed higher PY values than EU cultivars. The influence of the year modified the PY level only in Sielecka and Oregon cultivars (Figure 1). The PY in Stavchanka cultivar within the exclusion cage and seeds that were freely pollinated did not differ significantly due to the fact that seed coats are constituted of maternal tissue ( $p>0.05$; Figure 1$)$.

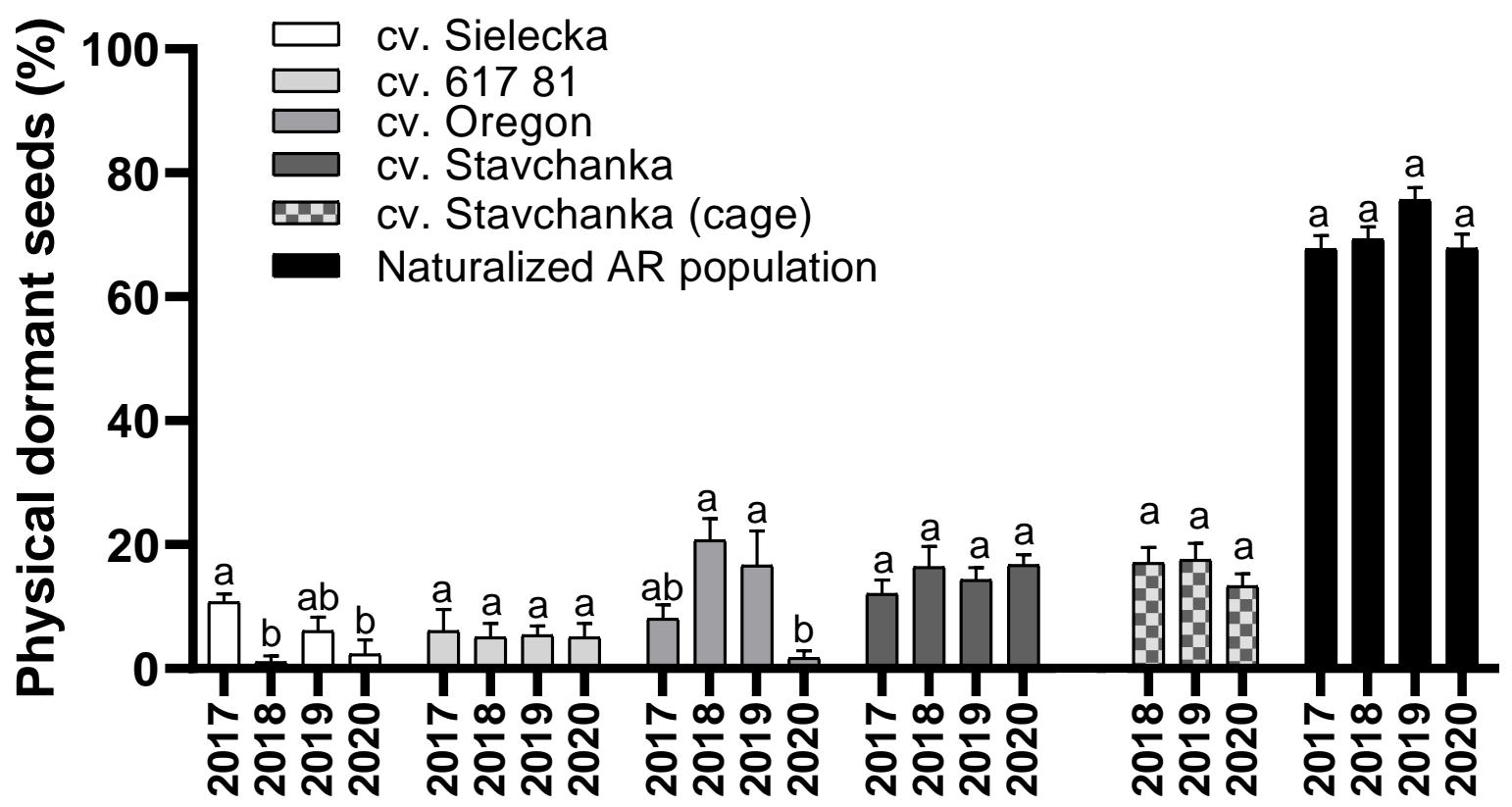

Figure 1. Percentage of seeds with physical dormancy (PY) for each genotype (mean and standard error) evaluated in a common garden during 2017-2020 with the first generation $\left(\mathrm{G}_{0}\right)$ from EU produced freely and Stavchanka in exclusion cages with honey bees (cage). Different letters indicate significant differences between years for each genotype (Fisher's LSD test, $\alpha=0.05$ ).

PY showed an interaction between genotypes and generations $(p<0.01)$. The AR showed a high and stable PY level ( $>67 \%$ ), while EU cultivars showed lower PY (Table 2). However, with the advance of the generations (from $\mathrm{G}_{0}-\mathrm{G}_{3}$ ), the PY level increased in all EU cultivars, except for Stavchanka during 2018 and 2019 (Table 2). Spontaneous crosses increased the degree of PY in EU cultivars. 
Table 2. Percentage of dormant seeds' PY (mean and standard deviation) of hairy vetch (HV) genotypes for each year and generation.

\begin{tabular}{|c|c|c|c|c|c|c|c|}
\hline \multirow{3}{*}{\multicolumn{2}{|c|}{ Generations \# }} & \multicolumn{4}{|c|}{ European Cultivars } & \multirow{2}{*}{$\begin{array}{l}\text { Naturalized AR } \\
\text { Population }\end{array}$} & \multirow{3}{*}{$\operatorname{LSD}(p<0.05)$} \\
\hline & & 61781 & Sielecka & Oregon & Stavchanka & & \\
\hline & & \multicolumn{5}{|c|}{ Physical Dormant Seeds (\%) } & \\
\hline \multicolumn{8}{|l|}{2017} \\
\hline & $\mathrm{G}_{0}$ & $5.3 \pm 6.0$ & $10.6 \pm 2.3$ & $8.1 \pm 4.0$ & $12.0 \pm 3.9$ & $67.8 \pm 3.8$ & $8.4^{* *}$ \\
\hline \multicolumn{8}{|l|}{2018} \\
\hline & $\mathrm{G}_{0}$ & $5.2 \pm 4.0$ & $1.0 \pm 1.7$ & $20.6 \pm 3.0$ & $16.4 \pm 5.8$ & $69.3 \pm 3.5$ & $8.6^{* *}$ \\
\hline & $\mathrm{G}_{1}$ & $25.0 \pm 3.0$ & $29.3 \pm 3.2$ & $38.0 \pm 1.7$ & $22.4 \pm 3.6$ & $66.1 \pm 2.0$ & $5.9^{* *}$ \\
\hline & $\operatorname{LSD}(p<0.05)$ & $0.14^{* *}$ & $0.18^{* *}$ & $0.12 *$ & NS & NS & \\
\hline \multicolumn{8}{|l|}{2019} \\
\hline & $\mathrm{G}_{0}$ & $5.3 \pm 2.0$ & $6.0 \pm 4.1$ & $16.8 \pm 9.7$ & $14.4 \pm 3.5$ & $75.7 \pm 3.6$ & $10.8^{* *}$ \\
\hline & $\mathrm{G}_{1}$ & $32.0 \pm 4.4$ & $27.1 \pm 2.6$ & $24.0 \pm 2.0$ & $32.0 \pm 9.1$ & $71.2 \pm 13.2$ & $13.9^{* *}$ \\
\hline & $\mathrm{G}_{2}$ & $20.0 \pm 4.1$ & $35.2 \pm 10.0$ & $48.0 \pm 7.2$ & $22.7 \pm 12.2$ & $70.3 \pm 8.1$ & $18.1^{* *}$ \\
\hline & $\operatorname{LSD}(p<0.05)$ & $7.4^{* *}$ & $12.8^{* *}$ & $14.4^{* *}$ & NS & NS & \\
\hline \multicolumn{8}{|l|}{2020} \\
\hline & $\mathrm{G}_{0}$ & $4.3 \pm 4.4$ & $2.3 \pm 4.0$ & $1.6 \pm 2.1$ & $16.7 \pm 2.9$ & $67.8 \pm 4.0$ & $7.3^{* *}$ \\
\hline & $\mathrm{G}_{1}$ & $6.7 \pm 1.5$ & $15.0 \pm 2.0$ & $28.7 \pm 1.1$ & $25.0 \pm 5.0$ & $72.2 \pm 4.3$ & $6.2^{* *}$ \\
\hline & $\mathrm{G}_{2}$ & $22.6 \pm 4.5$ & $20.0 \pm 2.6$ & $31.0 \pm 1.7$ & $36.4 \pm 5.8$ & $76.4 \pm 14.7$ & $14.7^{* *}$ \\
\hline & $\mathrm{G}_{3}$ & $37.0 \pm 0.8$ & $25.3 \pm 6.6$ & $41.3 \pm 5.1$ & $56.1 \pm 3.6$ & $75.7 \pm 9.1$ & $11.6^{* *}$ \\
\hline & $\operatorname{LSD}(p<0.05)$ & $5.9^{* *}$ & $7.8^{* *}$ & $5.6^{* *}$ & $8.4^{* *}$ & NS & \\
\hline Gener & rations $\times$ Genotype & & & ** & & & \\
\hline
\end{tabular}

\# This indicates that the seeds tested in $\mathrm{G}_{1}, \mathrm{G}_{2}$ and $\mathrm{G}_{3}$ were produced without isolation and likely crossed. * and ** indicates significance at $p<0.05$ and $p<0.01$. NS, not significant.

According to the mean projections (Figure 2), it could be expected that the PY level of EU cultivars after 6 years of the spontaneous crosses with the naturalized AR population would reach a similar value to the latter population $(\sim 70 \%)$.

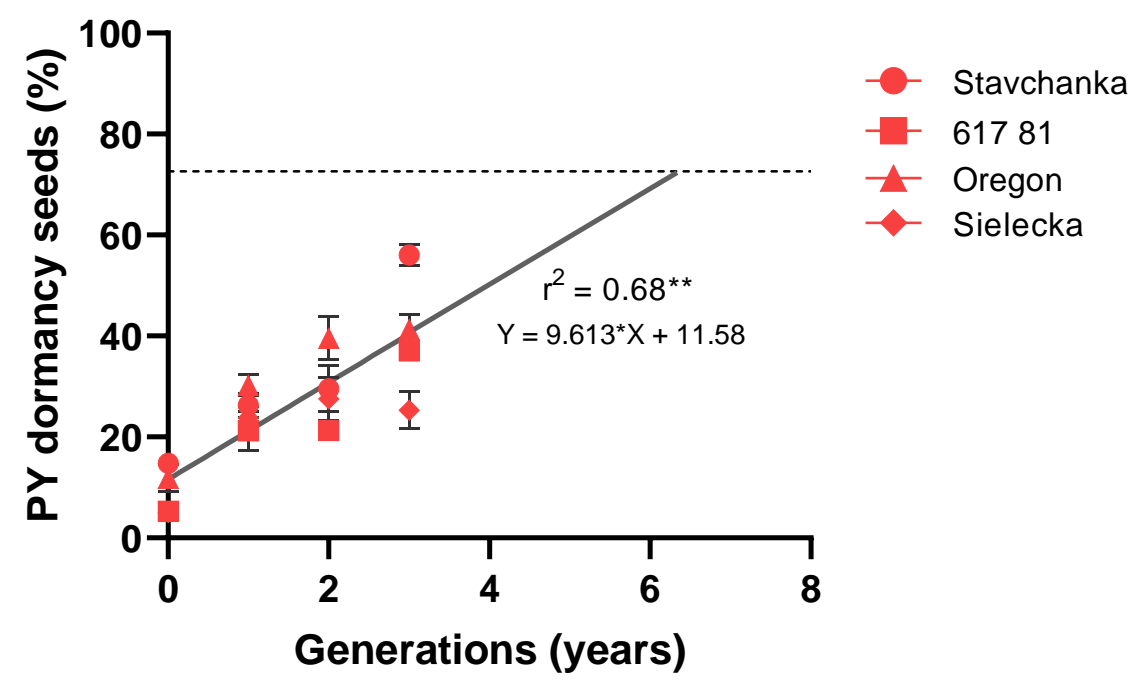

Figure 2. Projection of physically dormant seeds (PY) of EU cultivars (mean and standard error) as a function of generations of spontaneous crosses with a naturalized AR population. $\left.{ }^{* *} p<0.01\right)$

A faster rate of PY break was observed under summer compared to winter field conditions, due to the high temperatures $\left(>9.8^{\circ} \mathrm{C}\right)$ [11] increasing PY release (Figure S2). After 6 months and one year of burial, the PY levels ranged from $0-46 \%$ and $0-22 \%$, respectively, depending on the initial PY (Figure 3a). Completely eliminated seedbank persistence ( $0 \%$ PY) after one year was observed when the initial PY level was lower than $14 \%$ (Figure 3b, Table S1). 


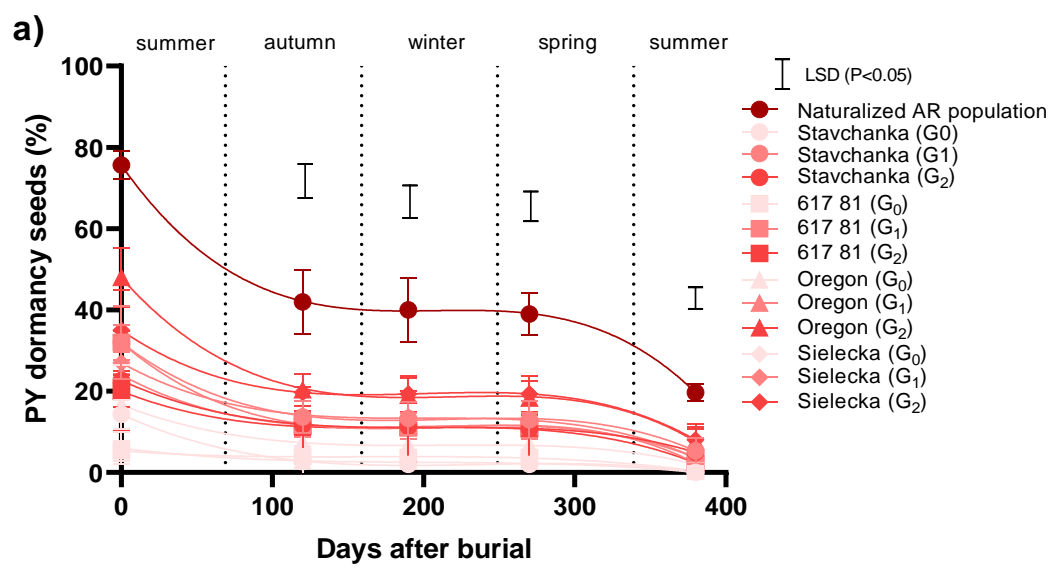

b)

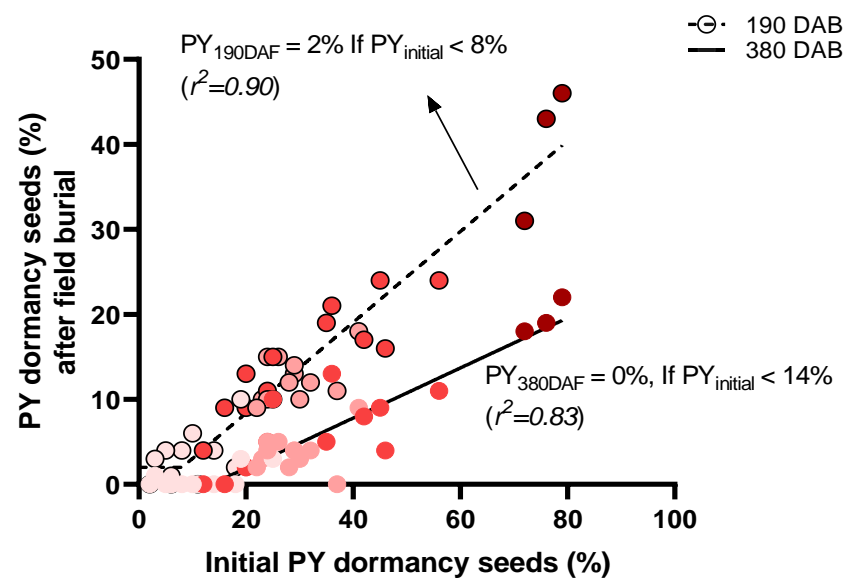

Figure 3. Percentage of physically dormant (PY) seeds for different genotypes and generations of hairy vetch as a function of days after burial (DAB) in field conditions during the 2019 growing season (a), and relation between PY at 190 and 380 days after field burial and initial PY (b).

Naturalized AR showed higher dry matter production compared to EU cultivars $\left(1229 \pm 258\right.$ vs. $\left.931 \pm 311 \mathrm{~g} \mathrm{plot}^{-1} ; p<0.01\right)$, but this difference was not observed as the generation of spontaneous crosses progressed $(p>0.05)$. DM was slightly related to increases in PY levels (Figure 4).

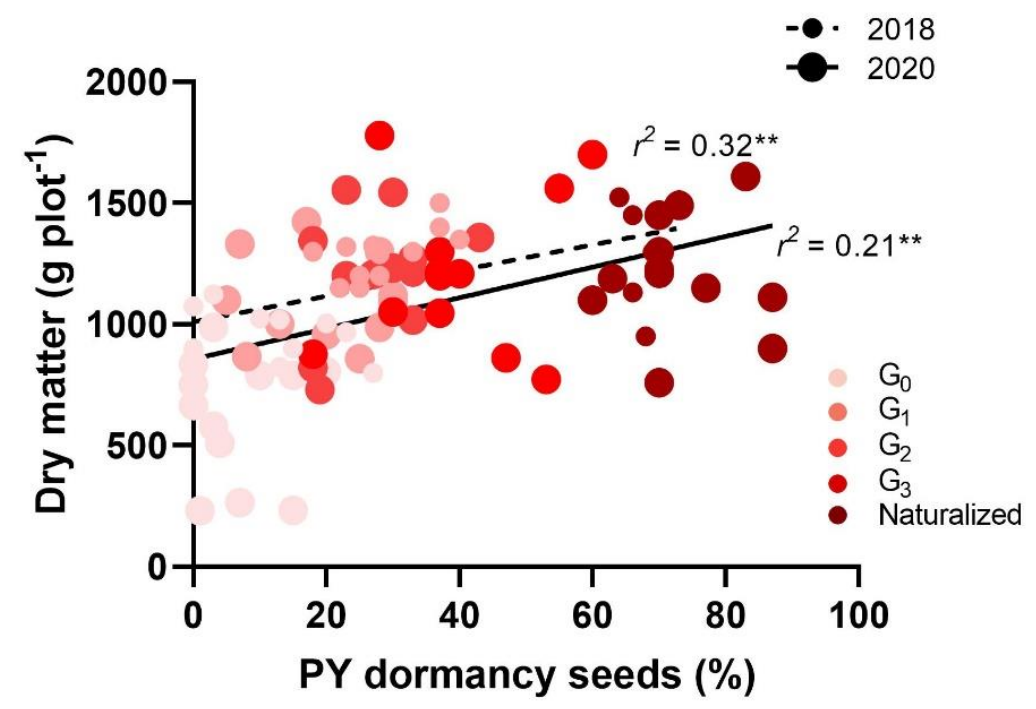

Figure 4. Dry matter per plot (DM) produced by hairy vetch during 2018 and 2020 in relation to the initial PY level of seeds. $\left.{ }^{* *} p<0.01\right)$ 


\section{Discussion}

The seed coat (testa) surrounding the embryo offers both physical and chemical protection against predation and microbial and fungal decay [28,29]. In particular, phenolic compounds seem to act as antioxidants, antimicrobial and anti-predation compounds [30-32] but also engage in the impregnation of the testa [33], which is involved directly in seed dormancy. Various polyphenols can be found in the seed coat, such as flavonoids, lignins and lignans. Several lines of evidence indicate that polyphenols influence both seed longevity and dormancy [32]. It has been shown that insoluble polyphenolic compounds contribute to seed coat hardness and the resulting seed dormancy [33-35].

Seed dormancy is largely genetically determined; however, it is also influenced by the environmental conditions experienced by the mother plant (maternal effect) and the subsequent degree of seed dehydration $[8,14,36]$. In our study of HV seeds growing under a semiarid environment, we observed that the environmental effect between years was lower than the genotypic effect (Figure 1). Appropriate conditions for seed development and drying would reduce the inter-annual variability in the acquisition of PY [6]. Our results indicated that the seed production environment under semiarid conditions had little effect on HV seed dormancy and that it is feasible to breed for the improvement of these traits by applying selection. The influence of the maternal environment may be greater in more contrasting year-site scenarios [8].

EU cultivars had lower PY values compared to naturalized AR populations. Observed differences between genotypes are likely explained by human selection during the improvement process $[12,37,38]$. Thus, special care must be taken when multiplying these improved genotypes to avoid contamination by gene flow. In our study, we observed that the PY level increased over the generations as the result of spontaneous crosses with high PY populations (Figure 1).

The naturalized AR population showed a higher biomass compared to original EU cultivars, probably due to the adaptation to Argentinian ecological conditions. It was shown that AR populations constitute an important reservoir of genes for high biomass production [6], but spontaneous crosses between EU cultivars and AR throughout the cycles $\left(G_{1}\right.$ to $\left.G_{3}\right)$ did not show difference in biomass production.

In our study, we observed that the total reduction of the seedbank persistence is unlikely within 6 months of the incorporation of seeds into the soil, and after 12 months, it is possible only when the initial PY was lower than $14 \%$ (Figure 3). However, these genotypes would not be suitable in ley farming practice, in which the success of annual crop rotation depends on the ability to provide an adequate plant density for seed/forage production by self-regeneration from the soil seedbank. On the contrary, from a weed management perspective, we observed that in HV genotypes with more than $70 \%$ of initial PY, the problem of "volunteer plants" can be avoided if management practices avoid seed production and seedbank replenishment for at least three consecutive years [17]. The selection breeding of cultivars with $<14 \%$ and $<8 \%$ of initial PY could reduce this period further to one year and 6 months, respectively.

Managing volunteer $\mathrm{HV}$ is particularly problematic in organic cereal production, where HV invasion could not be controlled by herbicides (synthetic auxins or sulfonylureas) in the winter cereal crop phase $[39,40]$.

The mechanical scarification process could reduce the proportion of PY seeds but also includes potential risks, such as low seed viability and associated operational costs [41,42]. Likewise, this management approach would not reduce the potential risk of weedy HV. Seed production and dispersal followed by a cereal crop or the incomplete termination of HV cover crop with plant regrowth and seed setting could result in the formation of seedbank and HV volunteer problems in successive crops [43,44].

In this sense, dedicated crosses between EU $\left(G_{0}\right)$ and $A R$ accessions and subsequent selection would serve to increase DM and reduce PY. With only one mating cycle, selecting $\left(E G_{1}\right)$ with $<14 \%$ of PY immediately after seed harvest and high DM in individual HV plants can satisfy both breeding objectives. It is important that the selection by low PY is 
carried out immediately after the harvest with careful threshing of the mature pods $(<14 \%$ of seed moisture). After harvest, PY release occurs rapidly at $>9.8^{\circ} \mathrm{C}$, and post-harvest conditions could impact PY $[8,11]$. Additionally, mechanical harvest reduces PY by $78 \%$, and it is easy to underestimate this trait considering natural seed dispersal [45].

Under natural conditions, dormancy has evolved as a bet-hedging strategy and is favored in temporally variable environments $[46,47]$. The prevention of the germination of a certain proportion of seeds reduces the risk of extinction once conditions become unfavorable. The physical dormancy of seeds of annual legumes is proposed to be broken down during fluctuating summer temperatures [48]. This mechanism prevents inopportune germination by protecting false germination before the onset of the autumn-winter rainy season [49], resulting in selection operating in natural habitats. Similarly, higher PY is favored in naturalized populations, and the gene flow to genotypes with low PY leads also to this adaptation [50].

Since high PY is not compatible with agronomical practices, it has been reduced during the domestication of crops and, in the case of less domesticated forages such as $\mathrm{HV}$, by breeding selection [8]. However, particularly in cases when wild relatives grow sympatrically and there are no crossing barriers, subsequent gene flow results in the occurrence of mostly genetically dominant wild traits in the resulting hybrid offspring, including seed dormancy [51].

\section{Conclusions}

Special care of the prevention of gene flow is required during the breeding and seed production of HV. This is especially relevant in situations such as the semiarid agroecosystem of Argentina where naturalized HV populations are well adapted. Spontaneous crosses with naturalized populations increase the degree of PY of the EU cultivars over breeding cycles. The effect of gene flow to the crop is not only of breeding and agronomical importance but can lead to the evolution of more aggressive invasive species [52]. Further studies of gene flow and isolation distance are needed.

The situation analyzed in this study of $\mathrm{HV}$, which is increasingly used as a cover crop, and respective naturalized populations widely distributed worldwide $[5,13,53]$ can be extended to other crops and particularly to forage species.

Supplementary Materials: The following are available online at https: / www.mdpi.com/article / 10.3390/agronomy11050955/s1, Figure S1: Mean daily temperatures and rainfall at EEA Hilario Ascasubi during the 2017, 2018, 2019, and 2020 growing season, Figure S2: Mean daily temperatures and rainfall at EEA Hilario Ascasubi during the 2019 burial field evaluation, Table S1: Percentage of physically dormant (PY) seeds (mean and standard deviation) for different genotypes and generations of hairy vetch as a function of days after burial (DAB) in field conditions during 2019 growing season.

Author Contributions: Conceptualization, J.P.R.; data collection, J.P.R., O.R., M.Q. data analysis, J.P.R.; writing - original draft preparation, J.P.R.; writing—review and editing, J.P.R. and P.S.; visualization, J.P.R.; supervision, P.S.; project administration, J.P.R.; funding acquisition, J.P.R. All authors have read and agreed to the published version of the manuscript.

Funding: This research was funded by Instituto Nacional de Tecnología Agropecuaria (INTA) PE-I142.

Institutional Review Board Statement: Not applicable.

Informed Consent Statement: Not applicable.

Data Availability Statement: The data presented in this study are available on request from the corresponding author.

Acknowledgments: Appreciation is extended to J. Castillo and M. Bruna, agricultural specialists, for assistance in establishing the field experiments. The authors would like to acknowledge V. Holubec of the Department of Gene Bank of the Crop Research Institute (CRI) and T. Vymyslický of the Research Institute for Fodder Crops for providing the cultivars of hairy vetch used in this study.

Conflicts of Interest: The authors declare no conflict of interest. 


\section{References}

1. $\quad$ van de Wouw, M.; Enneking, D.; Robertson, L.D.; Maxted, N. Vetches Vicia L. In Plant Genetic Resources of Legumes in the Mediterranean; Maxted, N., Bennett, S.J., Eds.; Kluwer: Dordrecht, The Netherlands, 2001; pp. 132-157.

2. Bryant, J.A.; Hughes, S.G. Vicia, in Wild Crop Relatives: Genomic and Breeding Resources Legume Crops and Forage; Kole, C., Ed.; Springer: Berlin/Heidelberg, Germany, 2011; pp. 273-289.

3. Francis, C.M.; Enneking, D.; Abd El Moneim, A. When and where will vetches have an impact as grain legumes? In Linking Research and Marketing Opportunities for Pulses in the 21st Century, Proceedings of the Third International Food Legume Research Conference, Adelaide, Australia, 22-26 September 1997; Knight, R., Ed.; Kluwer Academic Publishers: Dordrecht, The Netherlands, 1999; Volume 34, pp. 668-671.

4. Renzi, J.P.; Cantamutto, M.A. Vicias: Bases agronómicas para el manejo en la Región Pampeana. In Vicias: Agronomic Bases for Management in the Pampas; Ediciones INTA: Buenos Aires, Argentina, 2013; p. 299.

5. Aarssen, L.W.; Hall, I.V.; Jensen, K.I.N. The biology of Canadian weed: Vicia angustifolia L., V. cracca L., V. sativa L., V. tetrasperma (L.) Schreb. and V. villosa Roth. Can. J. Plant Sci. 1986, 66, 711-737. [CrossRef]

6. Renzi, J.P.; Chantre, G.R.; Smýkal, P.; Presotto, A.D.; Zubiaga, L.; Garayalde, A.F.; Cantamutto, M.A. Diversity of naturalized hairy vetch (Vicia villosa roth) populations in Central Argentina as a source of potential adaptive traits for breeding. Front. Plant Sci. 2020, 11, 189. [CrossRef]

7. Kissing Kucek, L.; Riday, H.; Rufener, B.P.; Burke, A.N.; Eagen, S.S.; Ehlke, N.; Krogman, S.; Mirsky, S.B.; Reberg-Horton, C.; Ryan, M.R.; et al. Pod dehiscence in hairy vetch (Vicia villosa roth). Front. Plant Sci. 2020, 11. [CrossRef] [PubMed]

8. Kissing Kucek, L.; Azevedo, M.D.; Eagen, S.S.; Ehlke, N.J.; Hayes, R.J.; Mirsky, S.B.; Reberg-Horton, C.; Ryan, M.R.; Wayman, S.; Wiering, N.P.; et al. Seed dormancy in hairy vetch (Vicia villosa roth) is influenced by genotype and environment. Agronomy $\mathbf{2 0 2 0}$ 10, 1804. [CrossRef]

9. Renzi, J.P. Efecto de la Estructura de Cultivo y Grado de Madurez a Cosecha Sobre el Rendimiento y la Calidad de Semillas de Vicia sativa L. y V. villosa Roth., Bajo Riego. Master's Thesis, Universidad Nacional del Sur, Buenos Aires, Argentina, 2009.

10. Hyde, E.O.C. The function of the hilum in some Papilionaceae in relation to the ripening of the seed and the permeability of the testa. Ann. Bot. 1954, 11, 241-256. [CrossRef]

11. Renzi, J.P.; Chantre, G.R.; Cantamutto, M.A. Development of a thermal-time model for combinational dormancy release of hairy vetch (Vicia villosa ssp. villosa). Crop Pasture Sci. 2014, 65, 470-478. [CrossRef]

12. Renzi, J.P.; Chantre, G.R.; Cantamutto, M.A. Effect of water availability and seed source on physical dormancy break of Vicia villosa ssp. villosa. Seed Sci. Res. 2016, 26, 254-263. [CrossRef]

13. Wayman, S.; Kissing Kucek, L.; Mirsky, S.B.; Ackroyd, V.; Cordeau, S.; Ryan, M.R. Organic and conventional farmers differ in their perspectives on cover crop use and breeding. Renew Agric. Food Syst. 2016, 32, 376-385. [CrossRef]

14. Hudson, A.R.; Ayre, D.J.; Ooi, M.K.J. Physical dormancy in a changing climate. Seed Sci. Res. 2015, 25, 66-81. [CrossRef]

15. Lacerda, D.R.; Lemos Filho, J.P.; Goulart, M.F.; Ribeiro, R.A. Seed dormancy variation in natural populations of two tropical leguminous tree species: Senna multijuga (Caesalpinoideae) and Plathymenia reticulate (Mimosoideae). Seed Sci. Res. 2007, 14, 127-135. [CrossRef]

16. Wilke, B.J.; Snapp, S.S. Winter cover crops for local ecosystems: Linking plant traits and ecosystem function. J. Sci. Food Agric. 2008, 88, 551-557. [CrossRef]

17. Renzi, J.P.; Chantre, G.R.; González-Andújar, J.L.; Cantamutto, M.A. Development and validation of a simulation model for hairy vetch (Vicia villosa Roth) self-regeneration under different crop rotations. Field Crops Res. 2019, 235, 79-86. [CrossRef]

18. Renzi, J.P.; Chantre, G.R.; Cantamutto, M.A. Self-regeneration of hairy vetch (Vicia villosa Roth) as affected by seedling density and soil tillage method in a semi-arid agroecosystem. Grass Forage Sci. 2017, 72, 535-544. [CrossRef]

19. Loi, A.; Howieson, J.G.; Nutt, B.J.; Carr, S.J. A second generation of annual pasture legumes and their potential for inclusion in Mediterranean type farming systems. Aust. J. Exp. Agric. 2005, 45, 289-299. [CrossRef]

20. Renzi, J.P.; Chantre, G.; Cantamutto, M.A. Vicia villosa ssp. villosa roth field emergence model in a semiarid agroecosystem. Grass Forage Sci. 2018, 73, 146-158. [CrossRef]

21. Zhang, X.; Mosjidis, J.A. Breeding systems of several Vicia species. Crop Sci. 1995, 35, 1200-1202. [CrossRef]

22. Petraityte, N.; Sliesaravicius, A.; Dastikaite, A. Potential reproduction and real seed productivity of Vicia villosa L. Biologija 2007, $53,48-51$.

23. Al-Ghzawi, A.A.; Samarah, N.; Zaitoun, S.; Alqudah, A. Impact of bee pollinators on seed set and yield of $V$. villosa spp. dasycarpa (Leguminosae) grown under semiarid conditions. Ital. J. Anim. Sci. 2009, 8, 65-74. [CrossRef]

24. Hunter, D.; Slate, J. Understanding genetic changes between generations. Proc. Natl. Acad. Sci. USA 2019, 116, 1834-1836. [CrossRef]

25. International Seed Testing Association. International Rules for Seed Testing; ISTA: Zürich, Switzerland, 2019; p. 300. [CrossRef]

26. Berger, J.D.; Shrestha, D.; Ludwig, C. Reproductive strategies in mediterranean legumes: Trade-offs between phenology, seed size and vigor within and between wild and domesticated lupinus species collected along aridity gradients. Front. Plant Sci. 2017, 8, 548. [CrossRef]

27. Di Rienzo, J.A.; Casanoves, F.; Balzarini, M.G.; Gonzalez, L.; Tablada, M.; Robledo, C.W. InfoStat Version 2013; Grupo InfoStat, FCA, Universidad Nacional de Córdoba: Córdoba, Argentina, 2013. 
28. Dalling, J.W.; Davis, A.S.; Schutte, B.J.; Arnold, A.E. Seed survival in soil: Interacting effects of predation, dormancy and the soil microbial community. J. Ecol. 2011, 99, 89-95. [CrossRef]

29. Fuerst, E.P.; Okubara, P.A.; Anderson, J.V.; Morris, C.F. Polyphenol oxidase as a biochemical seed defense mechanism. Front. Plant Sci. 2014, 5, 689. [CrossRef]

30. Hendry, G.A.F.; Thompson, K.; Moss, C.J.; Edwards, E.; Thorpe, P.C. Seed persistence: A correlation between seed longevity in the soil and ortho-dihydroxyphenol concentration. Funct. Ecol. 1994, 8, 658-664. [CrossRef]

31. Debeaujon, I.; Léon-Kloosterziel, K.M.; Koornneef, M. Influence of the testa on seed dormancy, germination, and longevity in Arabidopsis. Plant Physiol. 2000, 122, 403-414. [CrossRef] [PubMed]

32. Lepiniec, L.; Debeaujon, I.; Routaboul, J.M.; Baudry, A.; Pourcel, L.; Nesi, N.; Caboche, M. Genetics and biochemistry of seed flavonoids. Annu. Rev. Plant Biol. 2006, 57, 405-430. [CrossRef]

33. Smýkal, P.; Vernoud, V.; Blair, M.W.; Soukup, A.; Thompson, R.D. The role of the testa during development and in establishment of dormancy of the legume seed. Front. Plant Sci. 2014, 5, 351. [PubMed]

34. Moïse, J.A.; Han, S.; Gudynaite-Savitch, L.; Johnson, D.A.; Miki, B.L.A. Seed coats: Structure, development, composition, and biotechnology. In Vitro Cell. Dev. Biol. Plant 2005, 41, 620-644. [CrossRef]

35. Hradilová, I.; Duchoslav, M.; Brus, J.; Pechanec, V.; Hýbl, M.; Kopecký, P.; Smržová, L.; Štefelová, N.; Vaclávek, T.; Bariotakis, M.; et al. Variation in wild pea (Pisum sativum subsp. elatius) seed dormancy and its relationship to the environment and seed coat traits. PeerJ 2019, 7, e6263.

36. Finch-Savage, W.E.; Footitt, S. Seed dormancy cycling and the regulation of dormancy mechanisms to time germination in variable field environments. J. Exp. Bot. 2017, 68, 843-856. [CrossRef]

37. Fuller, D.Q.; Allaby, R. Seed Dispersal and crop domestication: Shattering, germination and seasonality in evolution under cultivation. In Fruit Development and Seed Dispersal; Ostergaard, L., Ed.; Blackwell: Oxford, UK, 2009; pp. $238-295$.

38. Kluyver, T.A.; Charles, M.; Jones, G.; Rees, M.; Osborne, L.P. Did greater burial depth increase the seed size of domesticated legumes? J. Exp. Bot. 2013, 64, 4101-4108. [CrossRef] [PubMed]

39. Crockett, B.C.; Mirsky, S.; Curran, W.S. Hairy vetch seed bank persistence as influenced by mechanical scarification and soil depth. In Proceedings of the 66th Annual Meeting of the Northeastern Weed Science Society, Philadelphia, PA, USA, 3-6 January 2012; p. 20. Available online: www.newss.org/proceedings/proceedings_2012.pdf (accessed on 20 March 2021).

40. Curran, W.S.; Wallace, J.M.; Mirsky, S.; Crockett, B.C. Effectiveness of herbicides for control of hairy vetch (Vicia villosa) in winter wheat. Weed Technol. 2015, 29, 509-518. [CrossRef]

41. Jacobsen, K.L.; Gallagher, R.S.; Burnham, M.; Bradley, B.B.; Larson, Z.M.; Walker, C.W.; Watson, J.E. Mitigation of seed germination impediments in hairy vetch. Agron. J. 2010, 102, 1346-1351. [CrossRef]

42. Mirsky, S.B.; Wallace, J.M.; Curran, W.S.; Crockett, B.C. Hairy vetch seedbank persistence and implications for cover crop management. Agron. J. 2015. [CrossRef]

43. Mischler, R.; Duiker, S.W.; Curran, W.S.; Wilson, D. Hairy vetch management for no-till organic corn production. Agron. J. 2010, 102, 355-362. [CrossRef]

44. Pittman, K.B.; Barney, J.N.; Cahoon, C.W.; Flessner, M.L. Influence of hairy vetch seed germination and maturation on weediness in subsequent crops. Weed Res. 2019, 59, 427-436. [CrossRef]

45. Renzi, J.; Cantamutto, M. Dormancia y germinación en semillas de Vicia villosa Roth. Anál. Semillas 2009, 3, 84-89.

46. Venable, D.L.; Brown, J.S. The selective interactions of dispersal, dormancy, and seed size as adaptations for reducing risk in variable environments. Am. Nat. 1988, 131, 360-384. [CrossRef]

47. Rubio de Casas, R.; Willis, C.G.; Pearse, W.D.; Baskin, C.C.; Baskin, J.M.; Cavender-Bares, J. Global biogeography of seed dormancy is determined by seasonality and seed size: A case study in the legumes. New Phytol. 2017, 214, 1527-1536. [CrossRef]

48. Norman, H.C.; Cocks, P.C.; Galwey, N.W. Hardseededness in annual clovers: Variation between populations from wet and dry environments. Aust. J. Agric. Res. 2002, 53, 821-829. [CrossRef]

49. Thompson, J.D. Plant Evolution in the Mediterranean; Oxford University Press: Oxford, UK, 2005. [CrossRef]

50. Ellstrand, N.C. Is gene flow the most important evolutionary force in plants? Am. J. Bot. 2014, 101, 737-753. [CrossRef]

51. Smýkal, P.; Nelson, M.N.; Berger, J.D.; Von Wettberg, E.J.B. The impact of genetic changes during crop domestication. Agronomy 2018, 8, 119. [CrossRef]

52. Magnussen, L.S.; Hauser, T.P. Hybrids between cultivated and wild carrots in natural populations in Denmark. Heredity 2007, 99, 185-192. [CrossRef]

53. Maul, J.; Mirsky, S.; Emche, S.; Devine, T. Evaluating a germplasm collection of the cover crop hairy vetch for use in sustainable farming systems. Crop Sci. 2011, 51, 2615-2625. [CrossRef] 